\title{
القيم التربوية هن آيات الدعاء في القران الكريم
}

م.م. عمار عبدالرزاق بابر المشايخي

مديرية تربية واسط

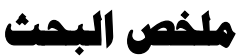

شغل الدعاء مكاناً كبيراً ومهمّاً من كتاب الله العزيز ولعَّك تلحظ تناثتر الدعاء من أوّل سورةٍ فيه مروراً بطو ال السور وقصسار ها مكيّها ومدنيّها حتّى إذا انتهينا عند آخر سور الكتاب المجيد وجدناها دعاءً

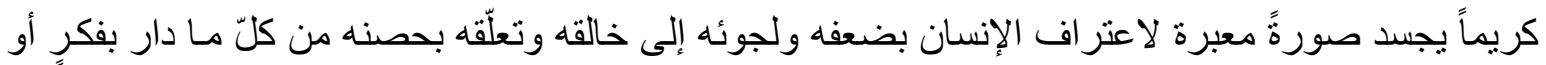
جال بخاطرٍ من أمرِ عظيم ،استعمل الباحث المنهج الوصفي التحليلي ولتحقيق هدف هذا البحث حدده الباحث

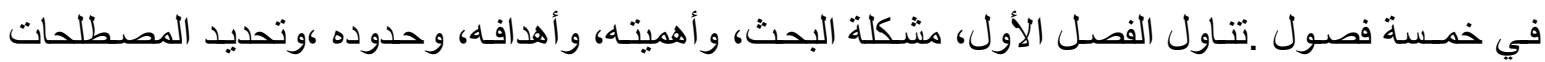
الواردة فيه. وتناول الفصل الثاني، الخلفية النظرية.

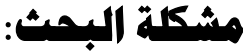

التربية القر آنية ربانية محكمة كاملة عالمية لا تعرف العشوائية ولا يضاهيها أي قانون وضعها البشر

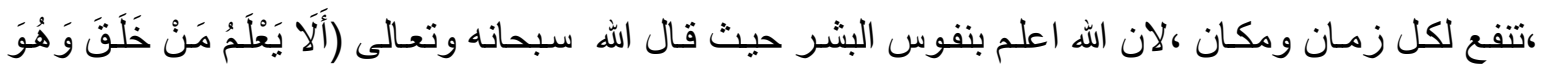

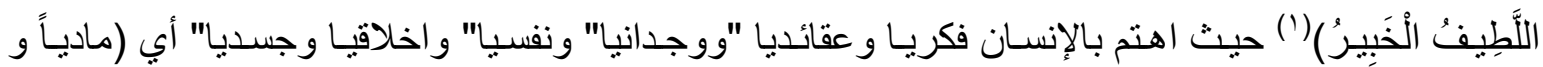
معنوياً) لذلك لم يمر مدى على العصور منهج تربويـة كما هو القران الكريم ، فلا يقتصر على العبادات

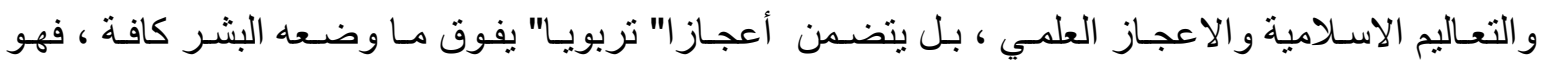
الدستور الحياتي والدنهاج التربوي لكل الناس على وجها الارض ليقوّم اعوجاج الانسان ويرشده الىى طريق

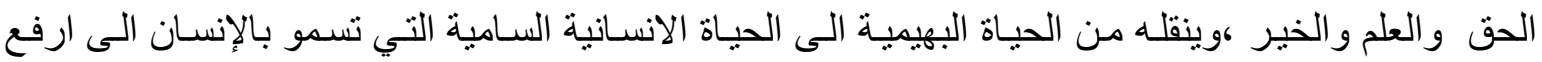

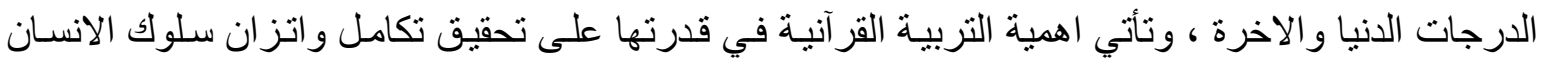

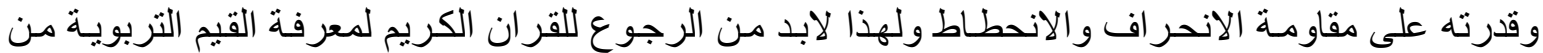
الآيات القر آنية وخاصة منها آيات الدعاء الذي هي موضوعة الآنه البحث .

فالدعاء هو حقيقة العبادة لان فيه العبودية وهو روح الطاعة لان فيه الاستجابة المخلصـة وهو قوام

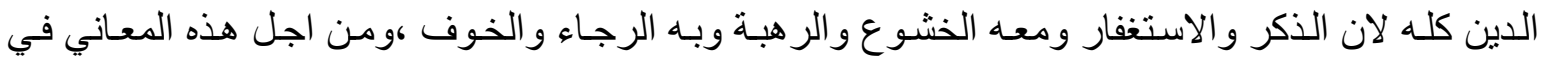
الدعاء وبسب انه هو العبادة نجد النبي المصطفى (صلى اله عليه وعلى الـه وسلم ) يحث بقوة على الدعاء حيث يقول (سلوا الله من فضله فان الله عز وجل يحب ان يسال وافضل العبادة انتظار الفرج) (؟).

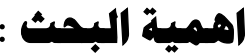

لذا إن المجتمـع بحاجـة ماسـة إلى قيم تربويـة أصـيلة معيار هـا القر آن الكريم، و الحـديث النبوي الثريف، واجتهادات العلماء العاملين، وآرائهم، وتصور اتهم حول بناء منهج تربوي بصفته الثمولية ، بحفظ لنا هويتـا العربية الإسلامية، ويرسخ قيمنا التربويـة، لتسهم في إعداد جيل مؤمن بدينه، وبأصـالة ماضيه، 
وو اقع حاضره، بالنحو الذي يتلائم مع استعدادات وقدرات أبنائنا في ضوء تعاليم الدين الإسـلامي الحنيف،

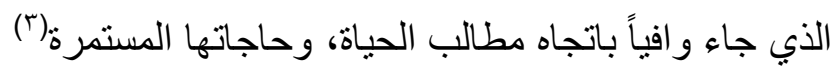

إما القيم الإسلامية فيصور ها القرآن الكريم، وقد تشكلت بصورة حيـة في أخـاق الرسول (صلى الله

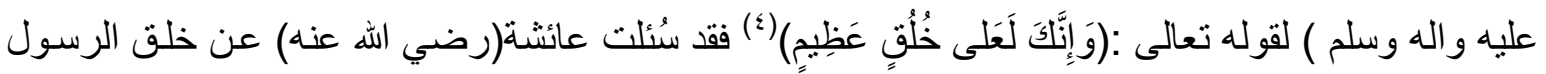
الكريم (صلى الله عليه واله وسلم) فقالت(كان خلقه القرآن)(ْ). وتمتاز القيم الإسلامية بخصائص كثثرة، أهلتها

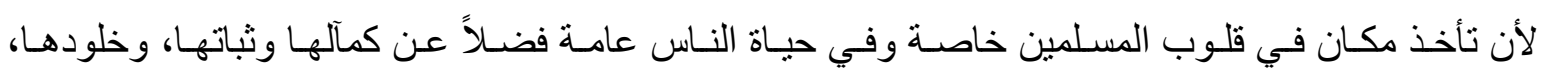
وو اقعتها، وملائمتها للفطرة، و المنهج المتكامل، الذي يثبع الروح و الجسد، ويرضـي العقل و العاطفة زيادة

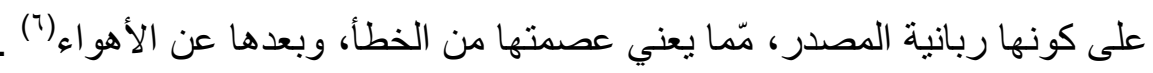
ولقد جاء الباحث لتبين اهمية الدعاء واظهار القيم التربويـة من آيـات الدعاء في القران الكريم ودلالاتها التربوية وتحث المربين و الاباء على كل حلقة علم او حلقة تربية بالدعاء و يا حبذا لوكان من القران الكريم .

\section{وبمكن تلفيص أهمية البمش بالشكل الأتي :}

1 اـاهمية الموضوع من كون الدعاء هو العبادة، وخير الدعاء هو ما اشتمل عليه القران الكريم.

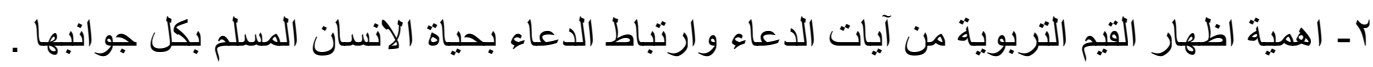

هدف البمش : اظهار القيم التربوية ومكانة الدعاء الوارد في آيات الدعاء في القرآن الكريم .

مدود البمث: تناول هذا البحث بيان القيم التربوية من آيات الدعاء في القران الكريم ودلالاتها التربويـة وتقتصر على القيم الايمانية و الاخلاقية و الاجتماعية.

\section{تمديد الإمhات:}

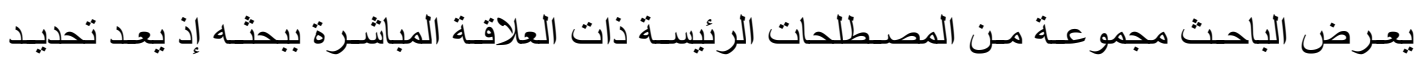

المصطلحات وتوضيح معانيها من مستلزمات البحث العلمي ، وذللك لأنه يعين الباحث في تكوين صورة منظمة لما يحيط به من معارف وحقائق ليدرك الكثير من الظو اهر والوقائع والعلاقات تحقيقا للفائدة العلميـة لهذه المفاهيم و المصطلحات ، وكلما تمكن الباحث من تحديد وتوضيح معاني مصطلحات البحث كان البحث دقيقا في منهجه و إجر اءاته إذ يسهل عند ذاك تحقيق أهدافه .

: 1 -1

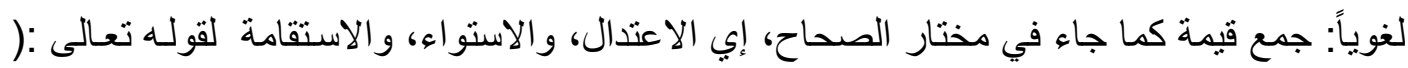

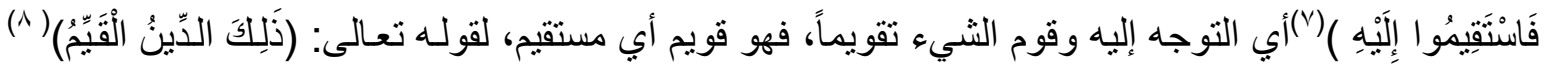
وقو ام الأمر ملاكه الذي يقوم به وقامة الإنسان قدَّه وجمعها قاما ( (9). 


\section{القيم اصطلاحك: عرفهها التربويون عدة تعاريف بأنها :}

مجموعة من الإحكام المعيارية المتصلة بمضامين و اقعيه يشر بها الفرد من خـلال انفعاله وتفاعله، مع المو اقف و الخبر ات ألمتنو عة ويشترط ان تنال هذه الإحكام قبو لاً من جماعة معينة، لكي تتجسد في سياقات الفرد السلوكية أو اللفظية أو اتجاهاته واهتماماته( · (').

\section{القيم الثزبوية :}

و هـي مجموعـة مـن المبـادئ و المفـاهيم و المواقف و السـلوك التـي تم استتباطها مـن القران الكريم

و الحديث النبوي الثريف كمنظومة تنطوي على إحكام معياريـة تربويـة يتم بموجبها تنشئة الأبناء ليمارسوا

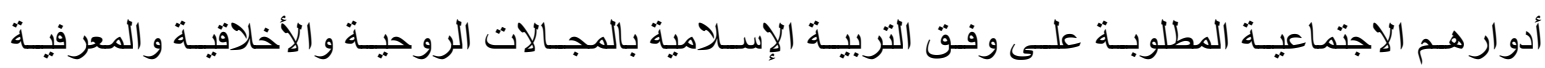
والاجتماعية) (')

تعريف الدهاء : الدعاء : استدعاء العبد ربه عز وجل العناية واستمداده اياه المعونة(r' ).

\section{النصل الثاني /الفلفية النظرية:}

الاول : معنى الدعاء: للدعاء هو العبادة ، فكل عبادة من العبادات المشروعة تتضمن الدعاء ، بل الصـلاة في

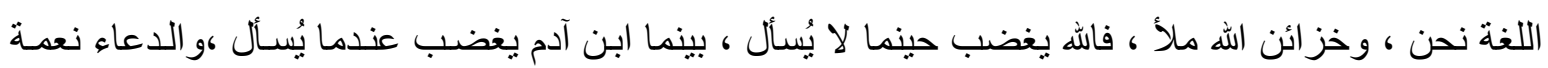
من نعمة الله علينا بها حتى ندفع عن انفسنا الابتلاءات وليكون لنا رحمة وشفاء من الامر اض ،فمـا خلق الله من داء الا وجد له الدواء ، فالدعاء يفرج عن المسلم كربته ويدفع عنه الثدة والبلاء ويجلب له الخير في الدنيا

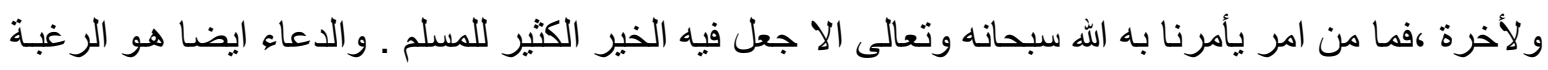
ال سبحانه وتعالى و الضر اعة اليهه ، وقد وردت مـادة الجذر(دعو) ومشتقاته حوالي مـائتين و اثنين وثمانين

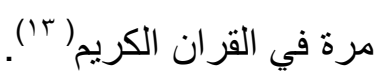
الدعاء مفتاح الرحمة فمن سره أن يستجيب الله دعاءه عند الثدائد فليكثر من الدعاء في الرخـاء وليكثر

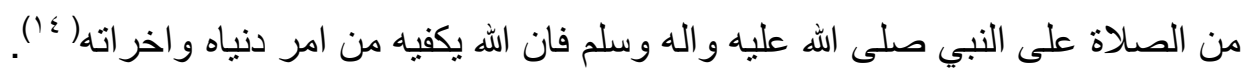
(دَعَا ) لفظ عربي أصله (ذَعَا ولأنّه من دعوت إلاّ أن الواو لما جاءت بعد الألف همزت) لذا ( فالدال والعين

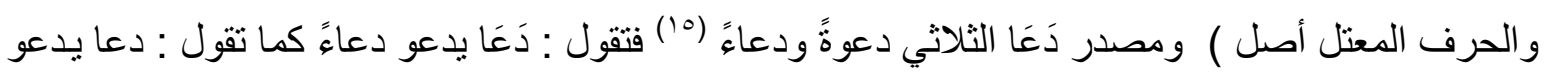

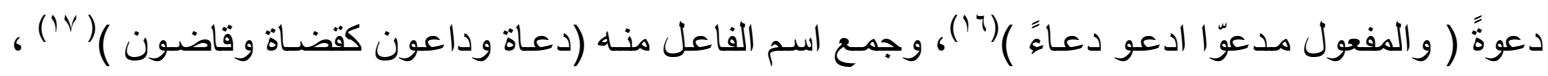

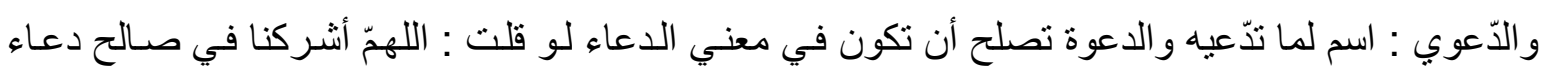
المسلمين و دعوي المسلمين ، جاز وحكي ذللك سيبويه و أنثد :

( قالت ودعواها كثير صخبه ) ( (1) ،ويطلق الدّعاء كصيغة مبالغة ( علي الشخص كثير الدعاء )( (19). و المؤمن يدعو ربه أينما كان وفي أب ساعة ، ولكن هذه الأوقات والأحوال و الأمـاكن تخص بمزيد عنايـة،

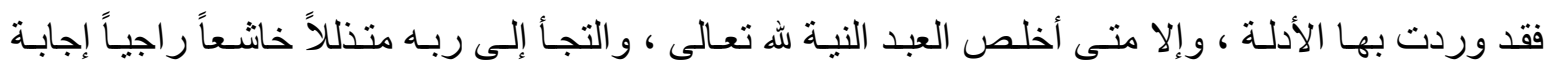

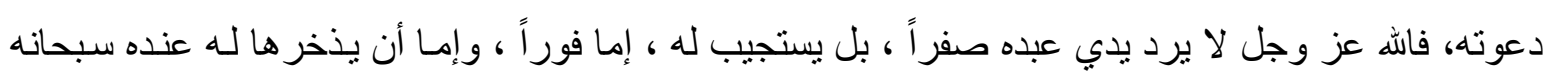

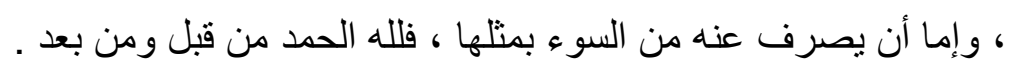




\section{ثانيا: أهمية الدعاء ومكانته عند المسلم .}

شغل الدعاء مكاناً كبيراً ومهمّاً من كتاب الهه العزيز ولعَّلك تلحظ تناثر الدعاء من أوّل سورةٍ فيه مروراً

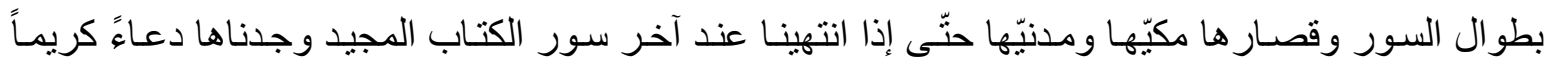

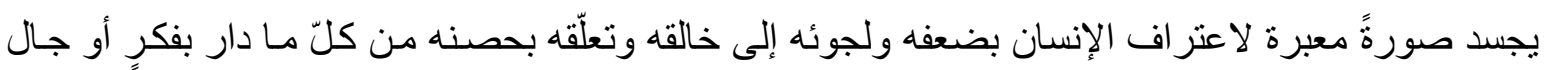
بخاطرٍ من أمرٍ عظبِ. من اراد اله ان بستجيب له عند الثندائد والكرب فليكثر من الدعاء في الرخاء وليكثر من الصلاة على

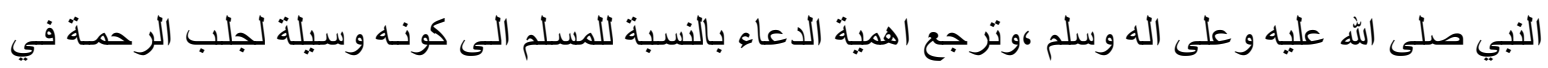

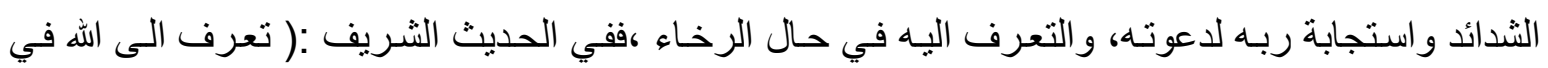

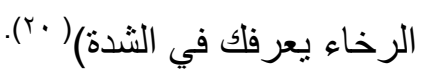

و لان الدعاء هو العبادة مثل كل العبادات المأمور بها، حيث امرنا الله سبحانه وتعالى في قولها: (وَفَّالَ

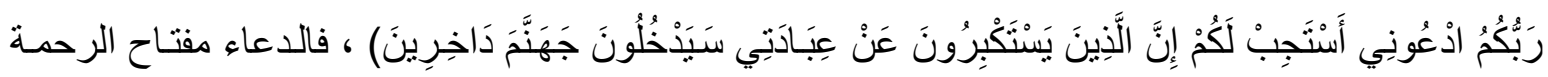
فمن سره ان يستجيب الله دعاءه عند الثندائد فليكثر من الدعاء في الرخاء وليكثر من الصلاة على النبي صلى

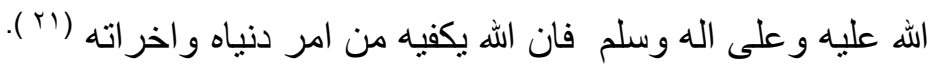

\section{ثالثا: صفات المدعو في القرآن( Tr (T):}

إنّما يستحق الدعاء حس نظرية القر آن الكريم الذي يمنلك الصفات التالية:

اـ القدرة و القوة والاستطاعة، عندما يصـاب البشر بشرٍّ، فعلى العاقل أن يبحث عمّن هو أقوى منه قدرةً

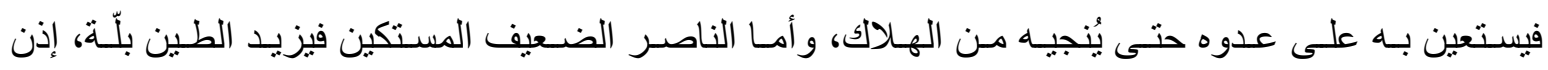

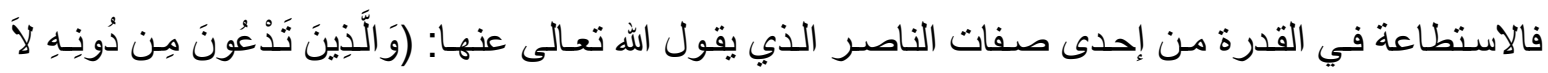

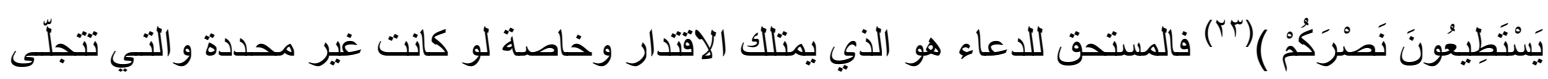

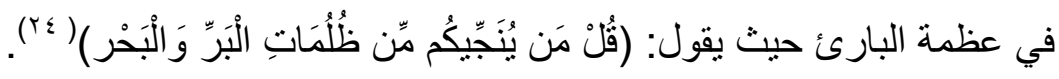

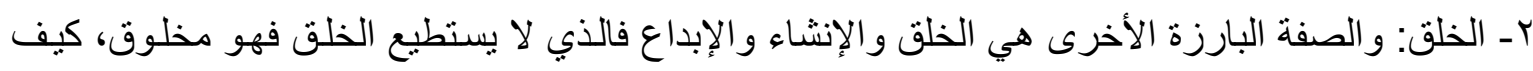

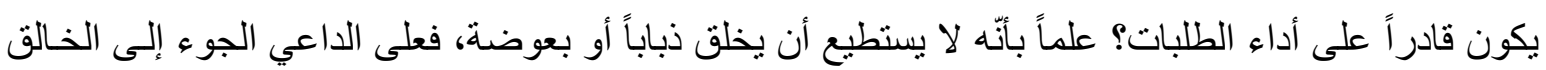

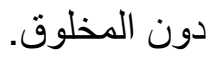
r- السمع: فـالأطرش و الأبكم الذي لايسمع الأصـوات ولا يدرك المعاني و اللدعوات كيف يستجيب لنداء

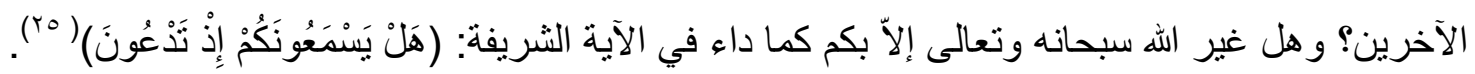

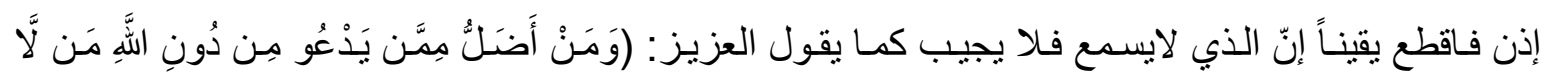

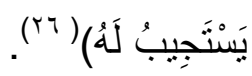

ع - التملك: فالمالك له حقّ التصرّف في ملكه عقلاً وعرفاً وشر عاً وفاقد الملك كيف يتصرّف في ملك غيره؟

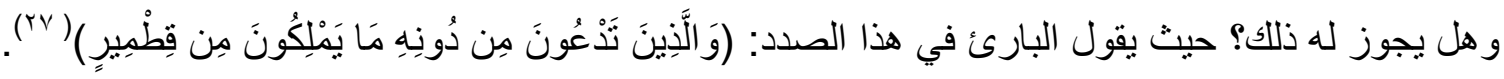


هـ النفع والضرر، فالذي يستحق أن ندعوه يجب أن يكون قادراً على دفع الضرر وجلب المنفعة، وهل غير

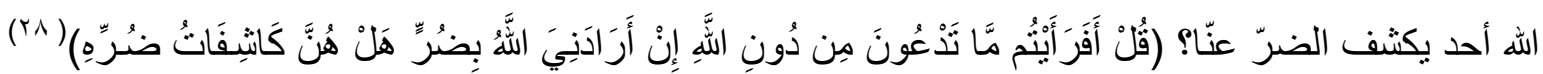

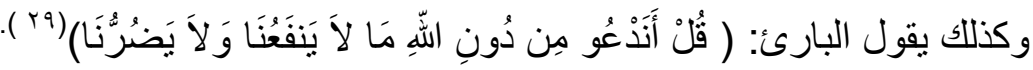

ד- العدل: من صفات المدعو أن يكون قاضياً بـالحقّ و العدل، حتى تسير الأمور في مجر اهـا و إلاّ فسيكون

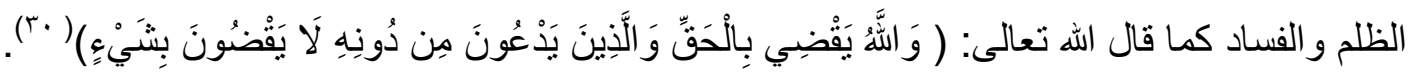
V- صاحب الثفاعة: فالمالك للثفاعة يُستوجب له الدعاء و لا شفاعة إلاّ بإذنه حيث يقول: (وَاللَّ يَقْضِي بِالْحَقِّ

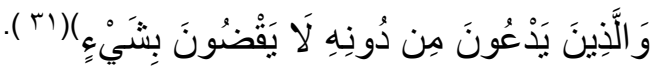

م- الأسماء الحسنى: فصاحب الأسماء الحسنى يستحق اللدعاء كما قـال تعالى:( وَللّهّ الأسَنْمَاء الْحُسْنَى فَادْعُوهُ بِهَا )(זr) و الحسنى مؤنت الأحسن، فأسماءه تعـالى الرحمن الرحيم والحيّ القيوم والسميع البصير و الخـالق الر ازق و المحي المميت و... حيث جـاء في الخبر... حيث جـاء في الخبر : ((إنّ لله سبحانه وتعـالى تسعة

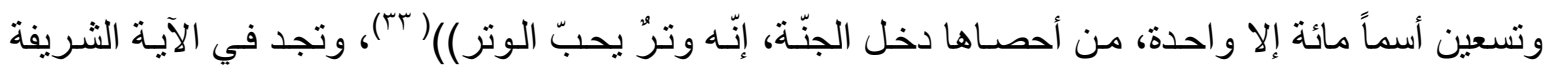
الآنفة الذكر ما يفيد الحصر من قوله تعالى (ولله) ومـا يُفيد العموم في قوله تعالى (الأسماء) حيث (آل) تدل على العموم، ثم قوله تعالى (فادعوه بها) أما من الدعوة بمعنى التسمية أو بمعنى النداء أو العبادة وقد أثنـارنا

إليها سابقاً.

\section{الفمل الثالث: دراسات سابقة}

سيعرض الباحث في هذا الفصل الثالث بعض الدراسـات والبحوث السـابقة التي تم تحديدها في ضوء هدفي البحث الحالي ،إذ إن الدراسات والبحوث هي تر اكم علمي على امتداد التاريخ الى الحاضر تبنى في

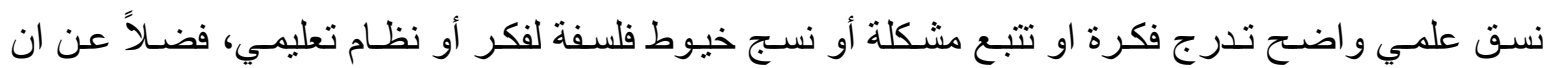

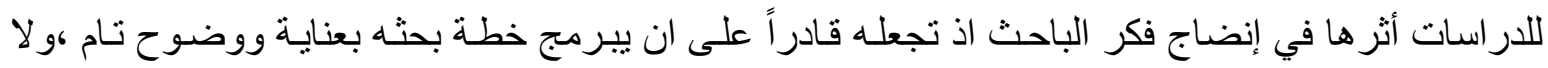

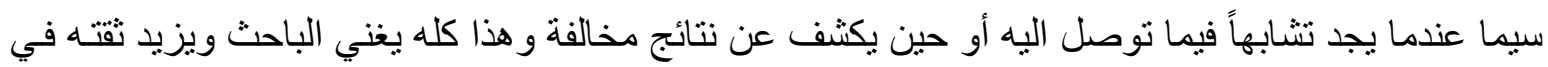
الاسترسال للوصول إلى هدفه، وتسليط الضوء على مشكلته و الاستز ادة في البحث و السير بخطى ثابتة ،لقد كـان موضـوع القيم مـن المو اضـيع التـي نالت اهتمـام المفكرين والعلمـاء والبـاحثين في الدر اسـات التربويـة و الفلسفية والاجتماعية ،مما دفعهم إلى إجر اء العديد من الدراسات و البحوث ،تنـاول البعض منها القيم السـائدة في المناهج الدراسية ولمختلف مراحل التعليم في حين تناولت دراسات أخرى القيم الأخلاقية و الصر اع ألقيمي و النسق ألقيمي وأخلاقيات مهنـة التربية و التعليم، وتسـهيلاً لمر اجعـة نتائج هذه الدراسـات فسيعرضـها الباحث بحسب نوعها وبحسب الترتيب الزمني لإجر ائها، وسيعرض الباحث الدراسـات على وفق خطـة تشتمل هدف

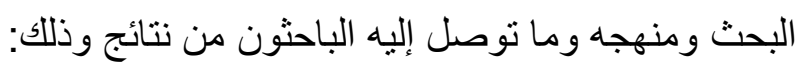

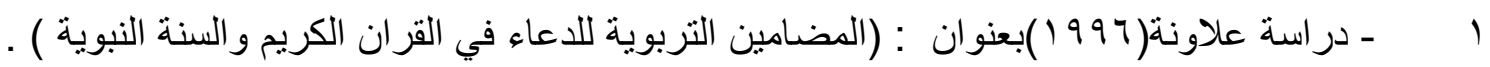
هدفت الدراسة الى استخلاص ابرز المضـامين التربويـة للداعاء في القران و السنة الثـريفة ،وذلك مـن خـلال جمع الادعية القر آنية والنبوية ودر استها كلا على حدة كمن حيث قامت الباحثة بتقسيم الادعية الى موضو عات 
عدة ،وبعد دراسة تحليلية في الكتاب التي تحدثت عنه وبخاصة كتب التفسير ،قامت الباحث باستخلاص ابرز المضامين التربوية .

ثم درست الباحثة كتب التربيـة الاسـامية للمرحلة الاساسية لمعرفة مدى وجود الادعيـة فيها ،وكيفية ورود هذه الادعية :

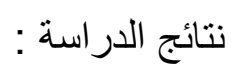
1-ان للاعاء اثار ا نفسية وسلوكية على الفرد و على المجتمع . r- ان الدعاء تضمن انتاجية ايجابية في خدمة الرسالة الايمانية .

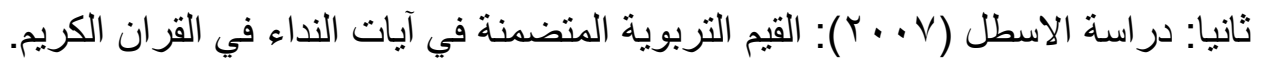
هدفت هذه الدراسة الى الكثف عن القيم التربوية آيات النداء القرآني للمؤمنين ووضع تصور مقترح لتوظيف هذه القيم في التعليم المدرسي ، وكذللك وضـع تصور مقترح لتوظيف هذه القيم في مواجهة التحديات التي

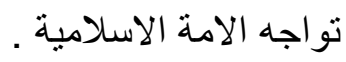

وقد استخدمت الباحثة المنهج الوصفي التحليلي ،باستخدام تحليل المحتوى وذلك بتحليل الآيـات التي تبدا بالنداء القرآني :( ياأيها الذين أمنو ا....) واستخر اج القيم من الآيات . اهم النتائج التي توصلت لها الباحثة:

ا -تزخر آيات النداء القر آني بالقيم التربوية الايمانية مثل : الايمان بالله وبرسوله ، قول الحق، التوبـة ،الرقابـة

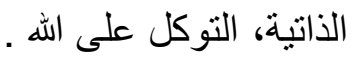
r-القيم الاخلاقية مثل : شكر الله ،التأدب مع الرسول ،العدل ،الوفاء، الحياء، التعاون . بـ القيم الاجتماعية: ومن هذه القيم التيسير على الناس، الاستئذان عند الدخول، الابتعاد عن الغلو. ع -القيم السياسية والعسكرية : مثل الجهاد في سبيل الله ،البر اءة من اعداء الله ،الثبات عند لقاء العدو . هـالقيم الاقتصادية مثل : الانفاق في سبيل الهه ،عدم التعامل بالربا، عدم كنز الاموال.

\section{مناقشة الدراسات السابقة:}

تباينت الدراسات السابقة من حيث الهدف الذي تسعى الى تحقيقه، فدر اسات هدفت الى التعرف على القيم التربوية وكان من اهداف بعض هذه الدر اسات هو بناء منظومة للقيم في ضوء ما توصلت اليه من نتائج. 1ـاهمية الدعاء للمسلمين كافة لإصلاح النفوس و اصلاح السلوك البشري ب-اهميـة الاخذ بـالآر اء التربويـة الاسـلامية ليستقيم الانسـان في حياتـه ،وتعليم أبنائـه كيفية الدعاء و افضل الاوقات و الاماكن و العمل للاستجابة من الله . 
بـاستفاد الباحث مـن الدراسـات السـابقة كيفيـة استخر اج القيم التربويـة مـن آيـات الدعاء في القران الكريم باستعمال المنهج الوصفي التحليلي.

وتتفق الدر اسة الحالية مع الدراسات السابقة من حيث المنهج وبيـان اهميـة الدعاء بالنسبة للمسلم وخاصـة اذا

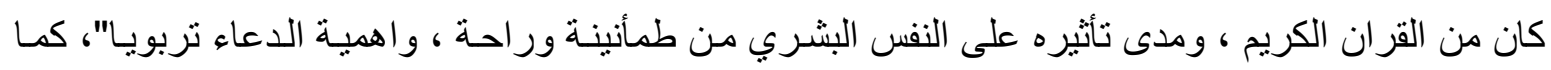

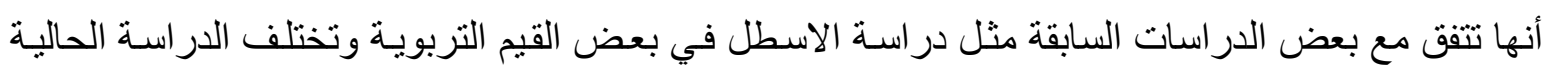
حيث انها تناولت آيات الدعاء في القران الكريم .

\section{الفمل الرابع / منهمية البمث وإمراء|ته}

1 -استخدام الباحث اسلوب تحليل المحتوى من خـلال من التحليل الآيـات القرآنيـة المتضـنة القيم التربوي للاعاء في القران الكريم .

r-وتعرّف طريقة تحليل المحتوى بأنها: مجموعة الخطوات المنهجية التي تسعى الى الكثف عن المعاني الكامنـة في المحتوى، و العلاقـات الارتباطيـة، بهذا المعنى مـن طريـق البحث الكميّ و الموضـوعيّ المـنظم

للسمات الظاهرة في هذا المحتوى (عَ ).

\section{النصل الفامس نتائه البمث وتفسيرها}

القران الكريم هو دستور المسلمين في بقاع الارض ،ما من مسلم اتبع تعاليمه الاعز وعلا شـانه، ومـا

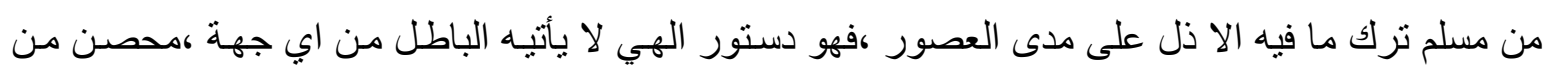

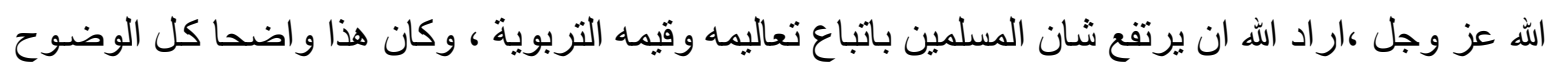

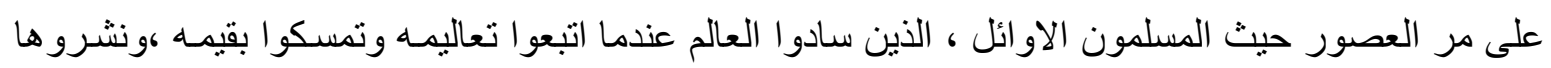
في بقاع الارض ، وكان الخير و الأمان و الحضارة الاسلامية العريقة التي نتوق اليوم الى احيائها وتطوير هـا ،و القيم التربويـة من آيات الدعاء في القرآن الكريم متعددة بتعدد جو انب حيـاة الانسـان الايمانيـة والاخلاقيـة و الاجتماعية ومن القيم الايمانية هي من اهم القيم التربوية آيات الدعاء في القران الكريم حيث انها الاسـاس

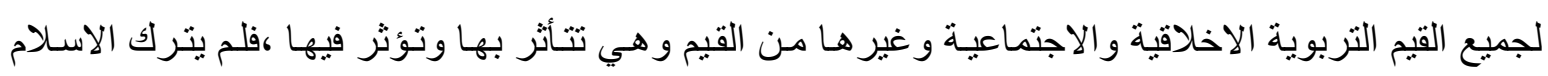
مجال في الحياة الاثر فيه ،وبين للمسلمين تعاليمه في هذا الاتجاه او ذلك ،وأول ما أبدأ بقيمـة الإيمانيـة لعقائديـة الروحية التي تنبثق منها جميع القيم الاسلامية اي اساس الاسلام وقو اعده مبنيه عليها .

\section{القبسمة الإيمانية:}

الإيمان بالله تعالى يُعدُّ المرتكز الأول في النظام القيمي الإسـلامي وهو القيمة الأعلى والأسـى التي

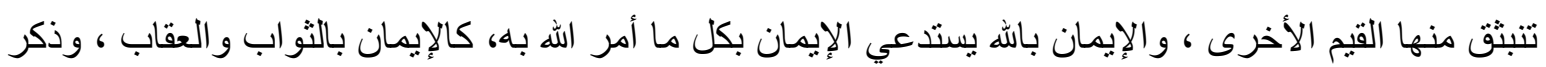

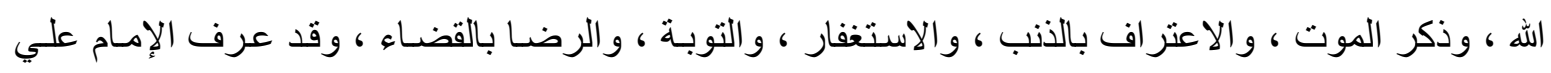

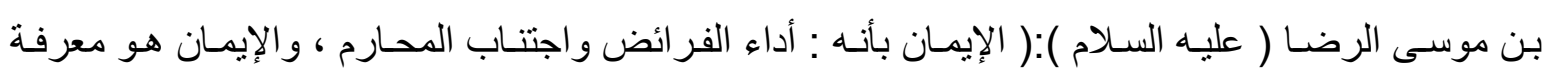
بالقلب و إقرار باللسان و عمل بالأركان ) (ro ). 
ويقصد بالقيمة الإيمانية هنا ، تللك العقيدة المتكاملة التي يتحرك بها المسلم في مجـال الحياة ، عابداً

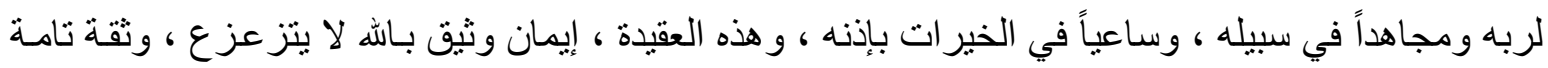

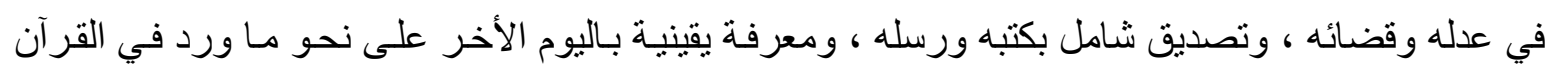
الكريم و السنة النبوية المطهرة ، و الإيمـان الحق بـالهه عز وجل لابـد من توفره على معرفة حقه بصفات الله

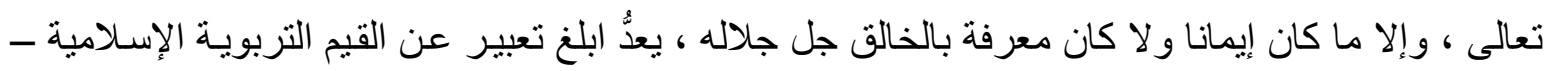

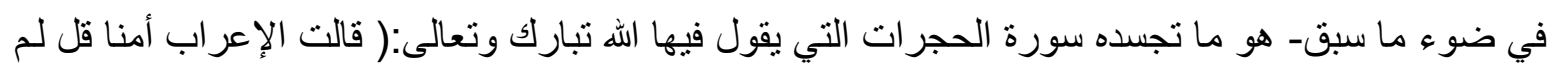

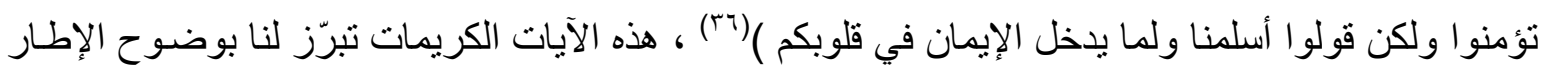

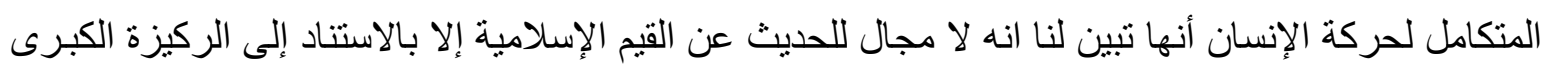

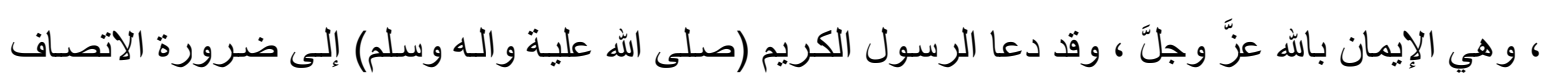

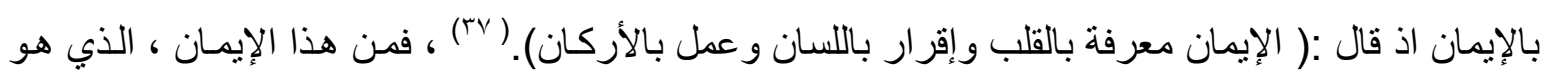

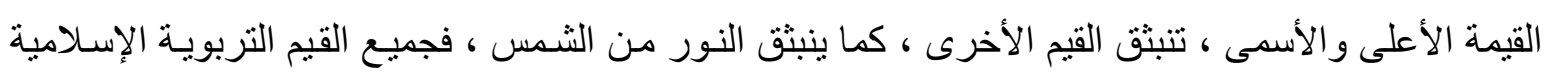

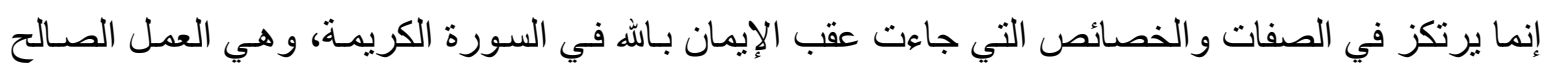
و التو اصي بالحق و التو اصي بالصبر ، وقد سُئلِّ الإمام علي بن أبي طالب ( عليه السـلام ) عن الإيمـان ، فقال

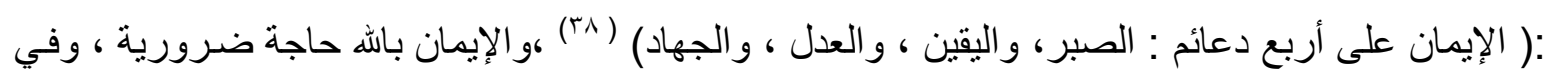
هذا الصدد قال باسكال : ( كل شيء غير اله لا يُشفيِي لنـا غليلاً ). ويرى الفيلسوف المعاصر الدوس وكسلي

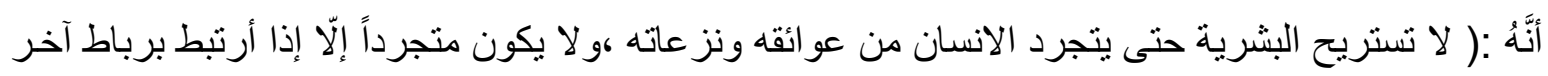

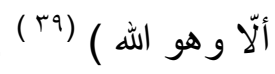

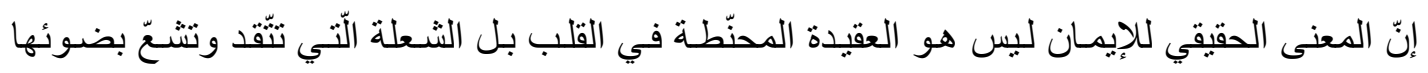

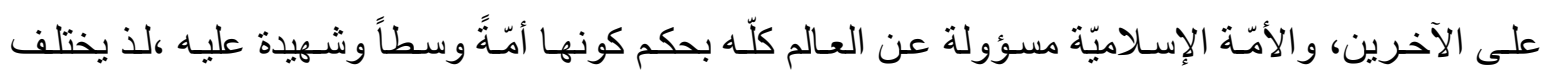

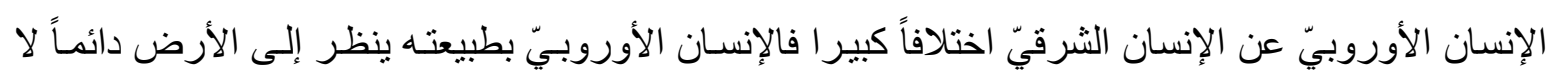

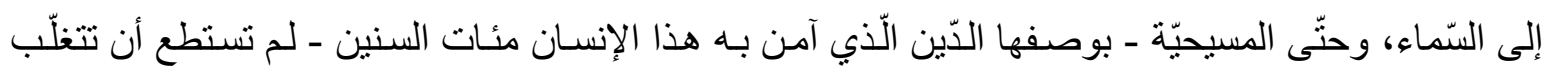

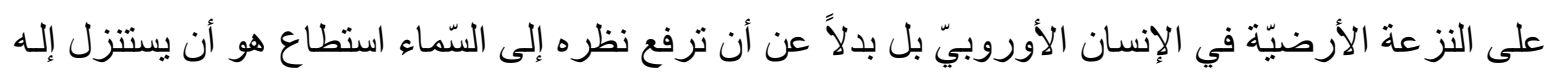

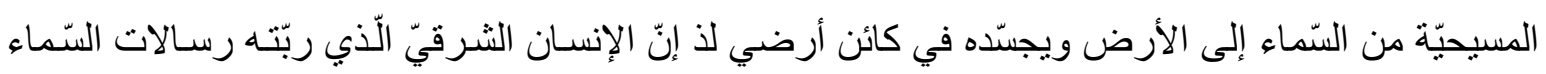

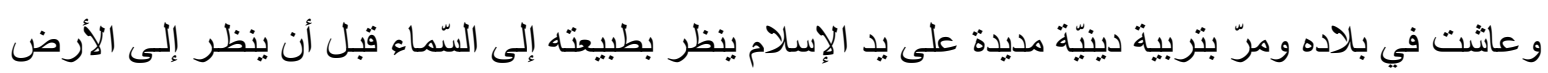

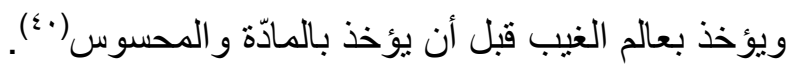

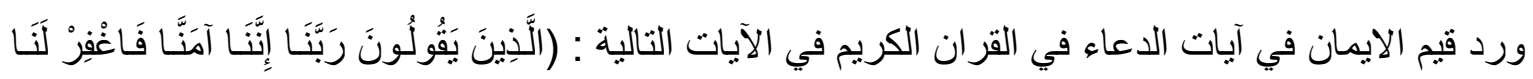

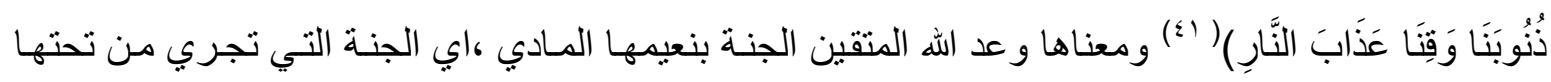

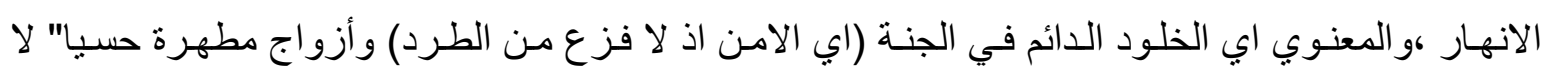

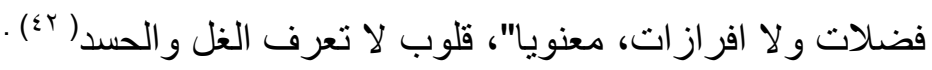




\section{القيمة الاخلاقية :}

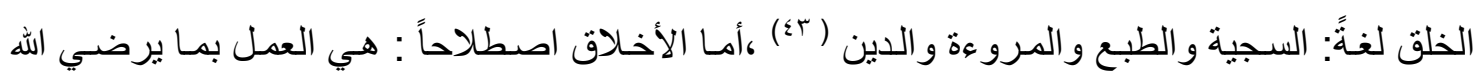

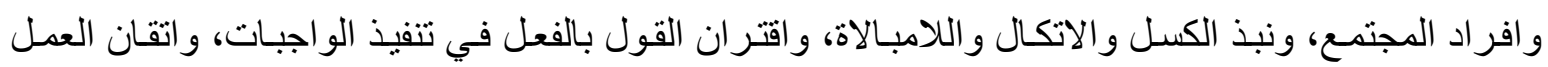
واجادته ( ؟ ؟). يؤكد الهاشمي على معنى الأخلاق و علم الأخلاق وتعريف المميز للأخلاق الإسلامية وكذلك وصفه لحسن

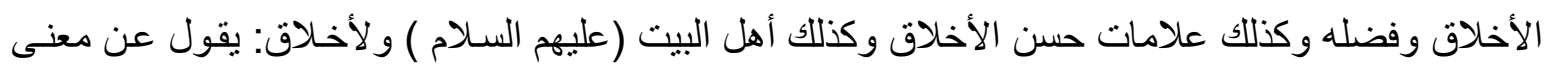

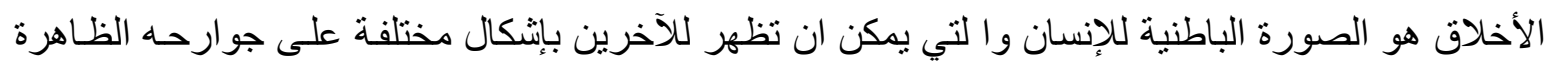

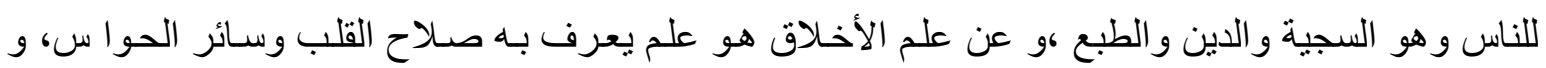

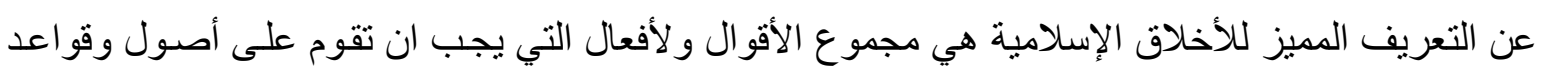

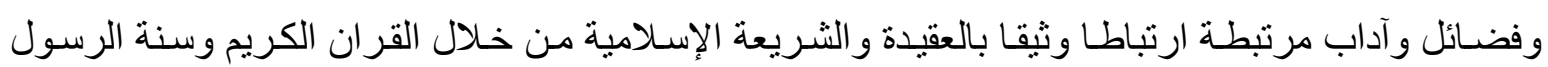

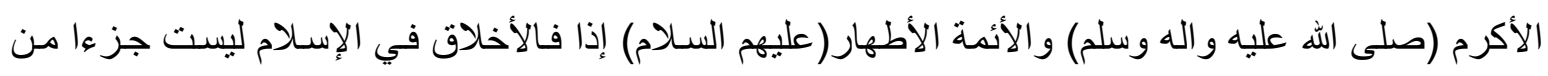

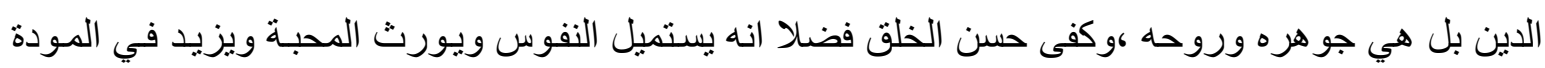
ويهدي إلى الفعل الحسن ولقد منَّ الله على المسلمين بأن جعل لهم قدوةً يقتدون بها، تتجسَّ فيها مكارم الأخلاق

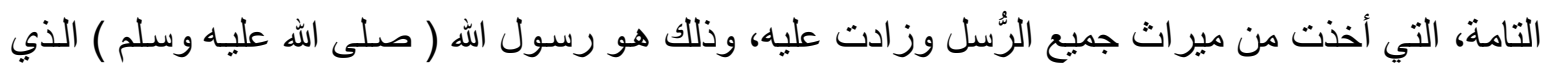

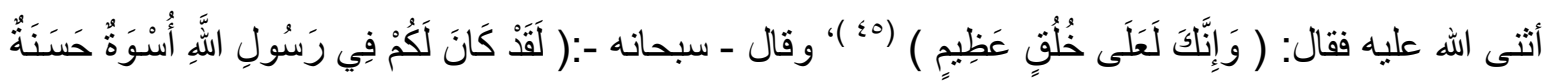

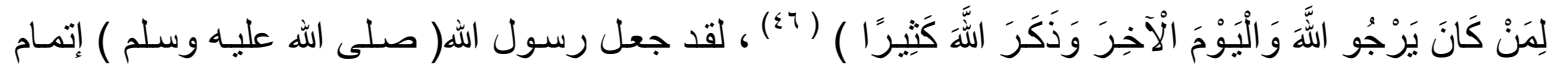

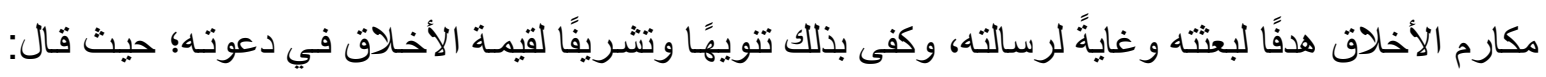

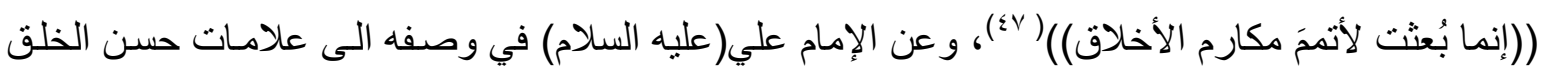

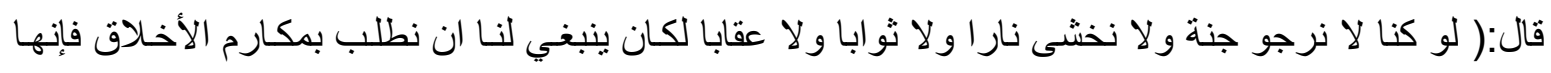

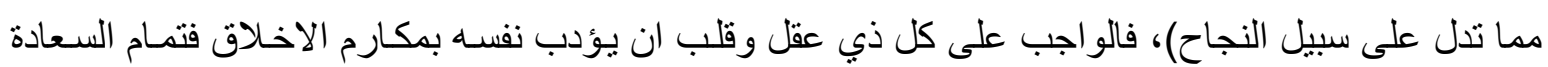

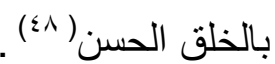

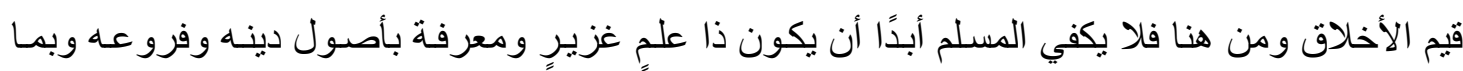

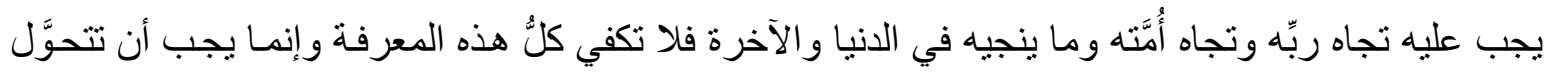

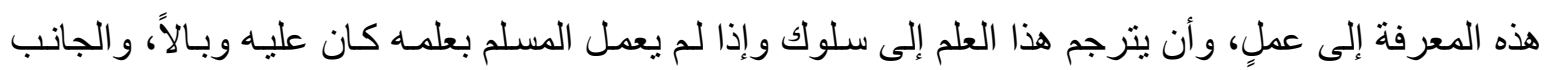

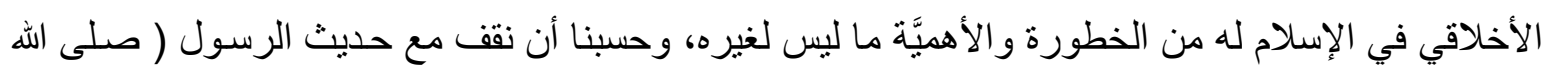

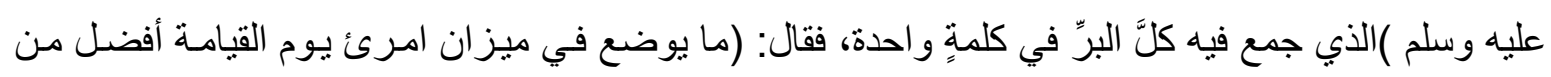

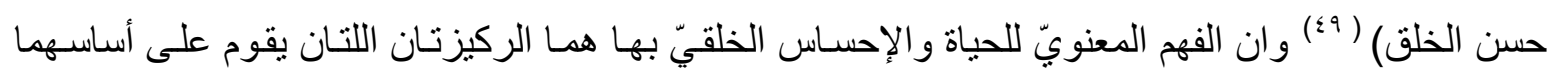

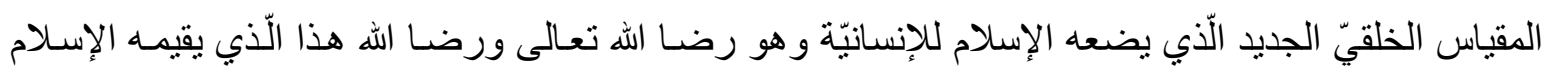

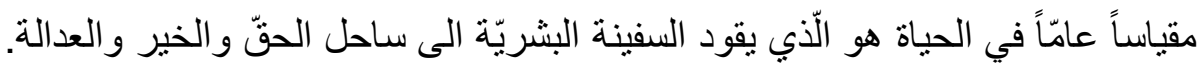




\section{القيمة الاجتماعية:}

هي الخصائص أو الصفات المرغوب فيها من الجماعة والتي تحددها الثقافة القائمـة مثل التسـامح والحق و القوة وهي أداة اجتماعية للحفاظ على النظام الاجتماعي و الاستقرار بالمجتمع. لغة القيمـة هي القدر والمنزلة و القيم الاجتماعية هي الخصائص أو الصفات المرغوب فيها من الجماعة وتوجه سلوكهم ،وهي التي تخبر هم

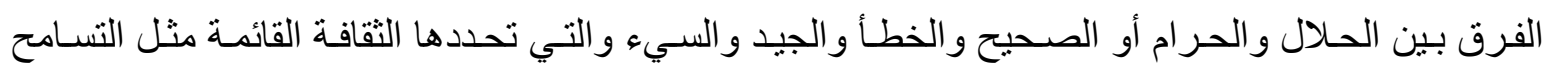

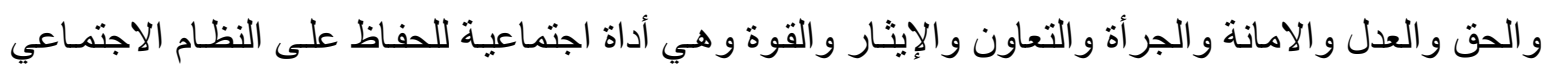
و والاستقرار بالمجتمع.

ان القيم الاجتماعية شاملة لجميع مناحي الحياة يعمل بها المجتمع ويجب أن يكتسبها المتعلم ومن امثلة هذا

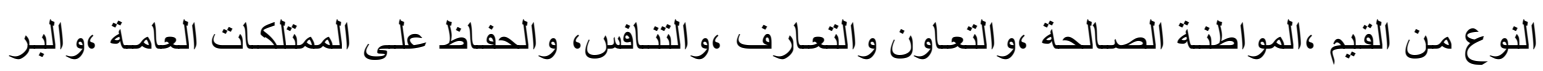
بالأخرين ،و التكافل الاجتماعي ،وحفظ النظام ،وحسن استثمار اوقات الفراغ ،و العمل ،و الايثار وفعل الخير

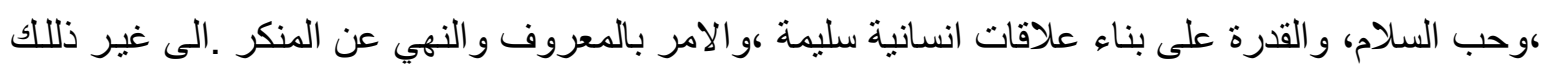
من القيم التي حث عليه القران الكريم ، و القيم الاجتماعيـة تتضمن القيم المتعلقة بالاهتهـام بالنـاس ،ومحبتهم و احتر امهم ومساعدتهم ،و الاحسان اليهم وخدمتهم والتعاون ،و الايثار ،و الصدق ،و الوفاء بـالو عود وبر الولدين

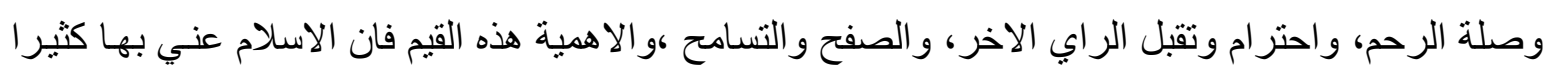

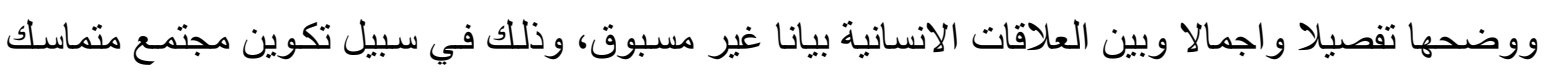

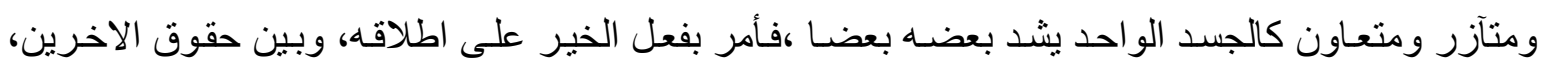
و التعامل معهم باحتر ام والصفح عن زلاتهم وايجاد الاعذار لهم بل والاحسان اليهم و اكر امهم (•).

|الاستنت:اجات :

بعد البحث و الدراسة توصل الباحث الى النتائج الاتية :

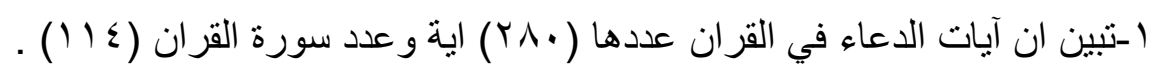
ז- تزخر آيات الدعاء بالقيم الايمانية منها: الايمـان بـاله، الحمد، والثكر، و لاستقامة، و الرحمـة، والمغفرة، وكما القيم الاخلاقية ومنها: الصبر، والصدق، والعلم، وكذلك القيم الاجتماعية منها: قيم الاخوة وبر الو الدين. זـ- من خلال استعرض القيم المتعلقة بالدعاء في هذه الدراسـة اتضـح أن القيمة الايمانية هـي اكثر من القيمـة الاخلاقية والقيمة الاجتماعية لأنها هي عماد الدين.

\section{التوصيات:}

في ضوء ما توصل اليه الباحث من استتناجات يورد التوصيات الاتية:

ا-غرس القيم التربوية المستمدة من آيات الدعاء في القران في نفوس المعلمين والمتعلمين عن طريق تضمين هذه القيم في الكتب المقررة على الطلبة. 
ז-أن تتبثق أهداف الخطط والمنـاهج المستقبلية من القيم التربويـة من آيـات الدعاء في القران الكريم لتغيير التعليم الى الافضل حتى يصل به الى ما يصبو اليه المسلم من خير ويو اكب التقدم العالمي . r-ان يسعى المربون الى غرس القيم التربوية الايمانية والاخلاقية المستمدة من ايات الدعاء في القران الكريم في نفوس الاجيال الصاعدة وحتى تخلق قيادات رشيدة تغير الحال المتردي للامة الاسلامية ، الى و اقع يحدوه الامل في الاستقرار النفسي و الاجتماعي والاقتصادي والسياسي ،وذللك بتعويد هذه الاجيال على التوكل على التى الله و الاخذ با لأسباب و الدعاء في جميع أمور الحياة

الاقتزحمات:

ا ـ عمل در اسة بعنوان كيفية الاستفادة من القيم التربوية من آيات الدعاء في التعليم وتربية النشء بتضمينها

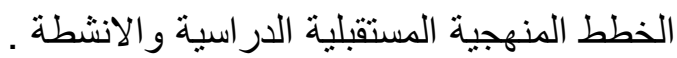

r-دراسة تبين الاثار السلبية للفضائيات وما تدخله علينا من قيم دخيلة ودور المؤسسـات التربويـة في مواجهة ذلك .

r-در اسة حول أهمية المؤسسات الاجتماعية والدينية في غرس القيم التربويـة الاسـلامية من آيـات الدعاء في القرآن الكريم في غرس القيم الاسلامية في المجتمع الاسلامي .

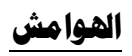

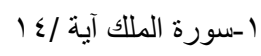

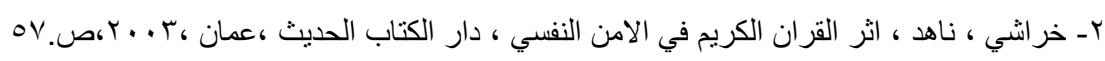

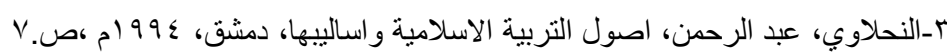
ع- سورة القلم آية .ع عابد

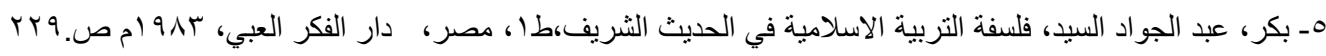

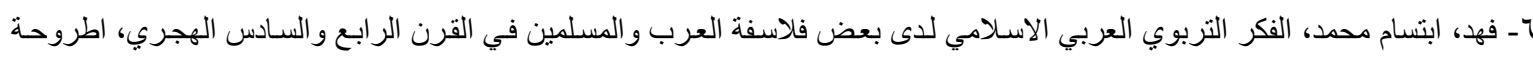

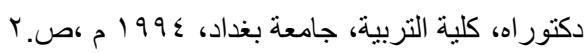

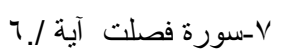

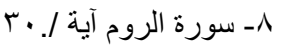

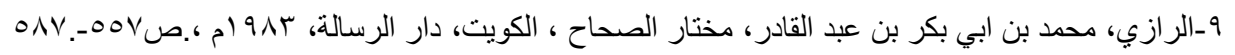

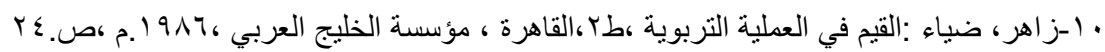

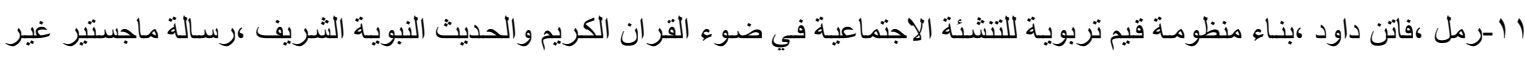

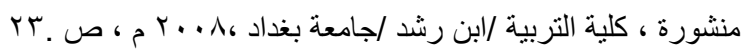

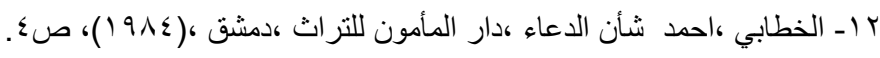

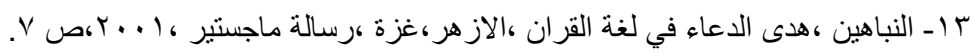

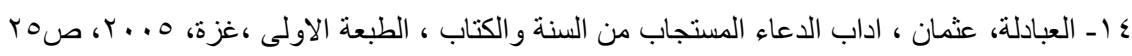

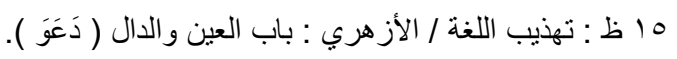

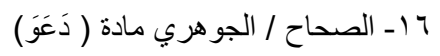
V ا ـ تاج العروس / الزبيري : مادة ( دَعَوَ ). 1 اـ مقاييس اللغة / ابن فارس ، باب العين والدال وما يثلنههما ( دَعَوَ ). 9 ا ـ جهرة اللغة / ابن دريد / مادة ( دَعَوَ ). 


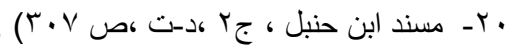

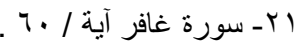

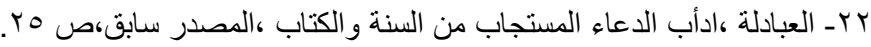

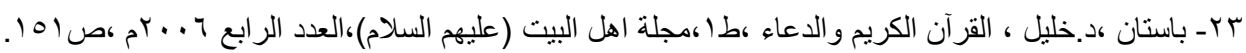

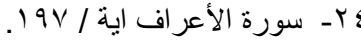

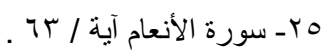

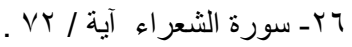

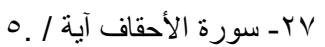

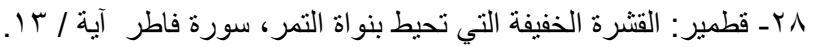

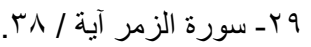

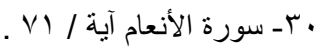

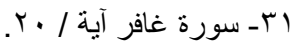

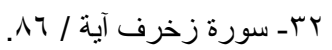

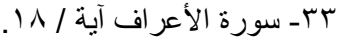

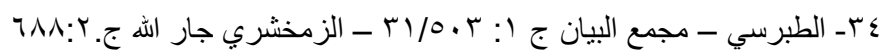

هب- عبد الحميد ،حمد: التحليل الكمي للمحتوى وبحوث الإعلام في ضوء المنظور المنهجي ، الحلقة الدراسية الثانية لبحوث الإعلام في

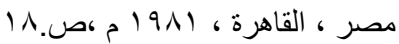
جrـ الحر اني ، أبو محمد الحسن بن علي بن الحسين بن شعبة ( القرن الرابع الهجري ): تحف العقول،طه،قم ، منشورات الثريف الرضسي،

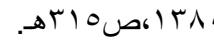
D.

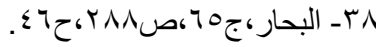

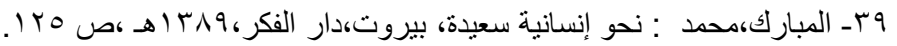

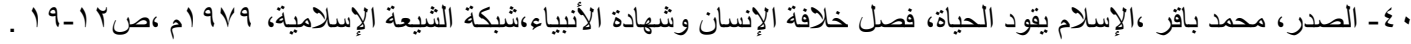

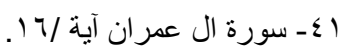

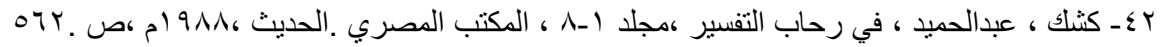

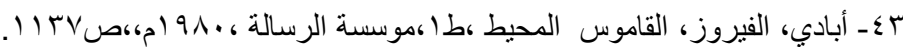

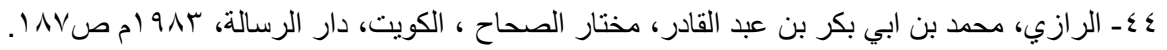

0ـ- سورة القلم آية /ع.

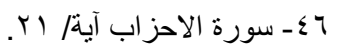

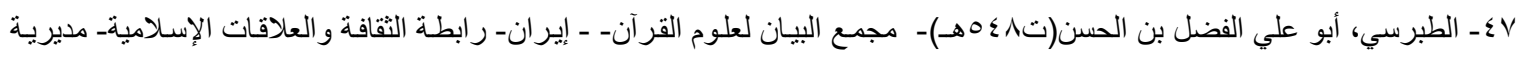

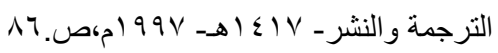

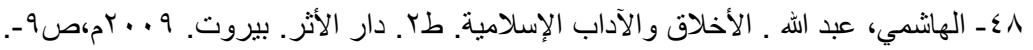

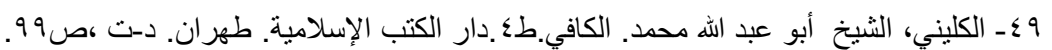
•0ـ الطيار، بسمة محمد سلطان : و اقع تناول عضو ات التدريس بجامعة الملك سعود للقيم في محاضرنهن من وجهة نظر الطالبات ،مجلة

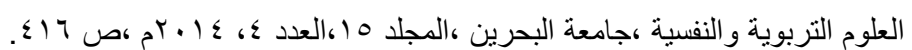

\section{المصادر العربية}

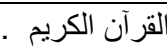

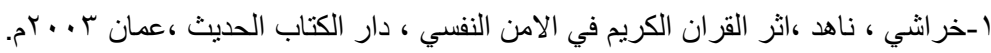

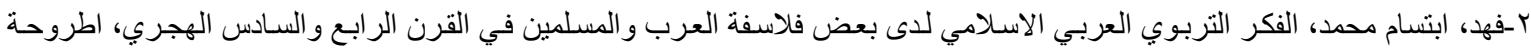

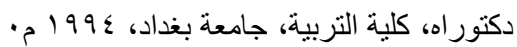

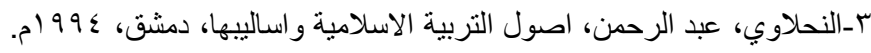

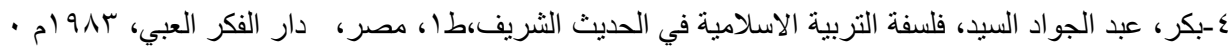




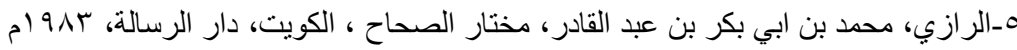

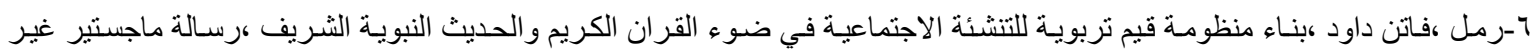

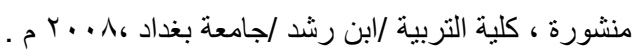

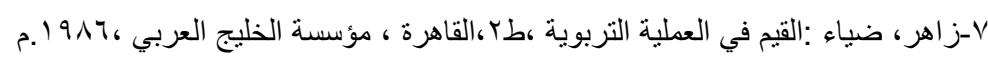

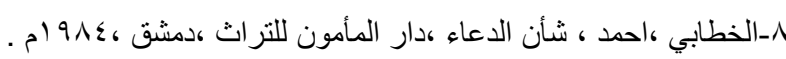

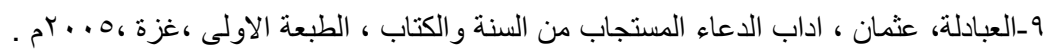

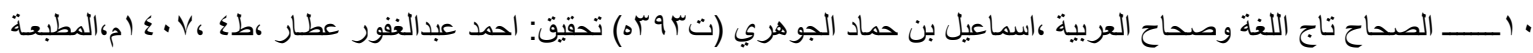

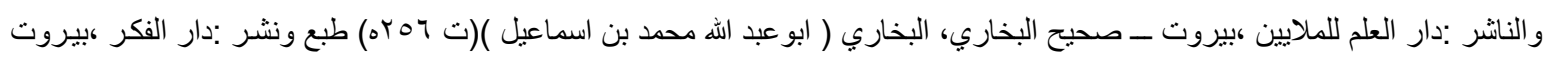
م $1911-01 \leqslant \cdot 1$

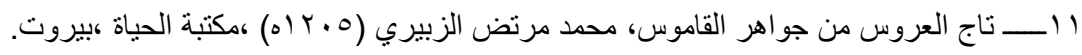

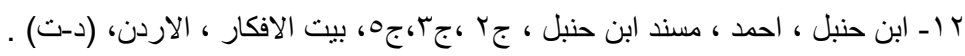

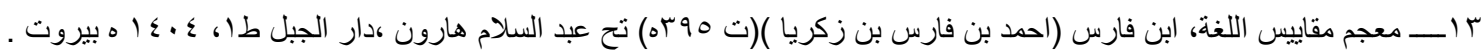

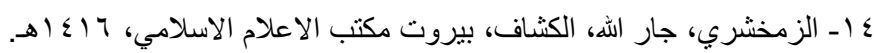

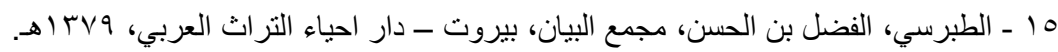

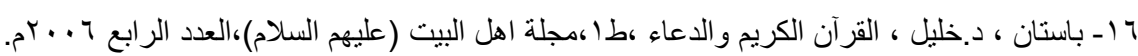

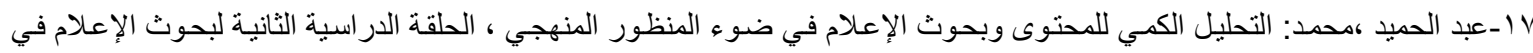

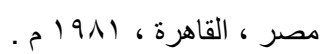
^1 ــ الحر اني ، أبو محمد الحسن بن علي بن الحسين بن شعبة ( القرن الر ابع الهجري ): تحف العقول،طه،قم ، منشورات الثريف الرضي، .

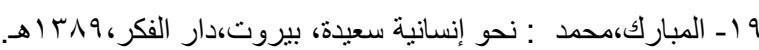

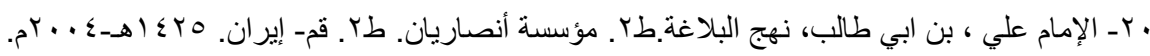

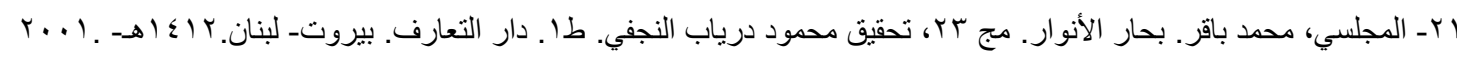

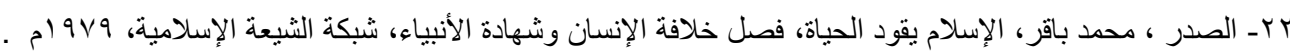

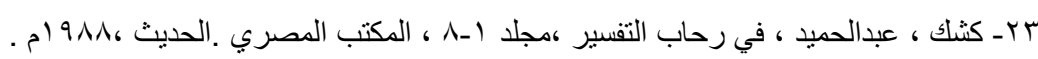

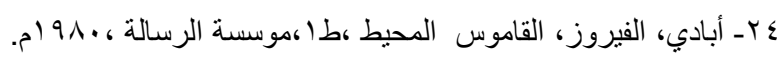

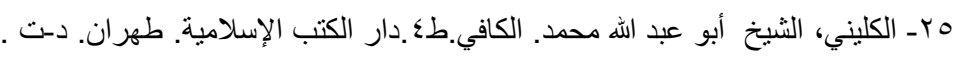

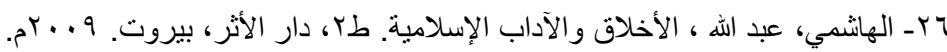

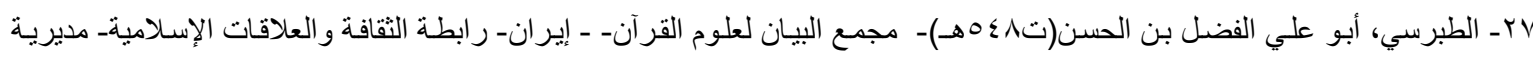

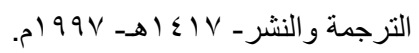

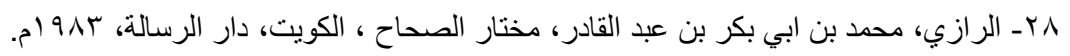

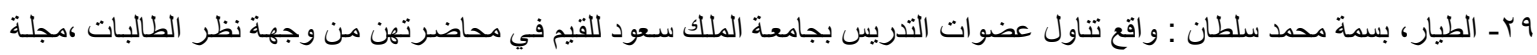

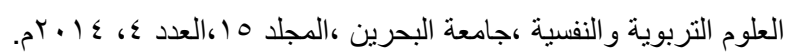

